\title{
Influence of Connector Groups on the Interactions of Substituents with Carbon-Centered Radicals
}

\author{
Ambili S. Menon, ${ }^{\dagger, \ddagger}$ Thomas Bally, ${ }^{\ddagger}$ and Leo Radom*, ${ }^{\dagger}$ \\ ${ }^{\dagger}$ School of Chemistry and ARC Center of Excellence for Free Radical Chemistry and Biotechnology, University of Sydney, Sydney, \\ NSW 2006, Australia \\ ${ }^{*}$ Department of Chemistry, University of Fribourg, CH-1700 Fribourg, Switzerland
}

Supporting Information

\begin{abstract}
High-level G3X(MP2)-RAD calculations have been carried out to examine the effect of interposing a "connector" group (W) on the interaction between a substituent $(\mathrm{X})$ and the radical center in carbon-centered radicals $\left({ }^{\circ} \mathrm{CH}_{2}-\mathrm{W}-\mathrm{X}\right)$. The connector groups include $-\mathrm{CH}_{2}-,-\mathrm{CH}=\mathrm{CH}-,-\mathrm{C} \equiv \mathrm{C}-,-p-\mathrm{C}_{6} \mathrm{H}_{4}-,-m-\mathrm{C}_{6} \mathrm{H}_{4}-$, and $-\mathrm{o}-\mathrm{C}_{6} \mathrm{H}_{4}-$, and the substituents include $\mathrm{H}, \mathrm{CF}_{3}, \mathrm{CH}_{3}, \mathrm{CH}=\mathrm{O}, \mathrm{NH}_{2}$, and $\mathrm{CH}=$ $\mathrm{CH}_{2}$. Analysis of the results is facilitated by introducing two new quantities termed radical connector energies and molecule connector energies. We find that the $-\mathrm{CH}_{2}-$ connector effectively turns off $\pi$-electron effects but allows the transmission of $\sigma$-electron effects, albeit at a reduced level. The effect of a substituent $\mathrm{X}$ attached to the $-\mathrm{CH}=\mathrm{CH}-$ and $-\mathrm{C} \equiv \mathrm{C}-$ connector groups is to represent a perturbation of the effect of the connector groups themselves (i.e., $\mathrm{CH}=\mathrm{CH}_{2}$ and $\mathrm{C} \equiv \mathrm{CH}$ ).
\end{abstract}

\section{INTRODUCTION}

A wide range of reactions in synthetic organic chemistry, ${ }^{1}$ polymer chemistry, ${ }^{2}$ biochemistry, ${ }^{3}$ and inorganic chemistry ${ }^{4}$ exploit the effect of substituents on the thermodynamic stabilization or destabilization of carbon-centered radicals. An understanding of the factors that influence their thermodynamic stability is therefore very important. ${ }^{5}$ There have been numerous experimental ${ }^{6,7}$ and theoretical ${ }^{8,9}$ studies to quantify how proximate substituents, i.e., substituents directly attached to the carbon radical center, affect free radical stabilities.

A common measure of the effect of a substituent $\mathrm{X}$ on the stability of a carbon-centered radical is the radical stabilization energy (RSE). For a monosubstituted radical $\left({ }^{\bullet} \mathrm{CH}_{2} \mathrm{X}\right)$, the RSE is given by the energy change for the hydrogen-transfer reaction:

$$
{ }^{\bullet} \mathrm{CH}_{2} \mathrm{X}+\mathrm{CH}_{4} \rightarrow \mathrm{CH}_{3} \mathrm{X}+{ }^{\bullet} \mathrm{CH}_{3}
$$

The RSE measures the effect of $\mathrm{X}$ on the stability of the radical - $\mathrm{CH}_{2} \mathrm{X}$ relative to its effect in the closed-shell parent $\left(\mathrm{CH}_{3} \mathrm{X}\right)$, with $\mathrm{CH}_{4}$ and ${ }^{\bullet} \mathrm{CH}_{3}$ being included as the reference (unsubstituted) species. Defined in this way, a positive value for the RSE implies a net stabilization of the substituted radical with respect to the reference radical, relative to the same effect in the parent closedshell species, whereas a negative value implies a net destabilization.

The RSE of eq 1 can equivalently be regarded as the difference between the homolytic $\mathrm{C}-\mathrm{H}$ bond dissociation energy (BDE) of methane and $\mathrm{CH}_{3} \mathrm{X}$ :

$$
\mathrm{RSE}\left({ }^{\bullet} \mathrm{CH}_{2} \mathrm{X}\right)=\operatorname{BDE}\left(\mathrm{CH}_{4}\right)-\operatorname{BDE}\left(\mathrm{CH}_{3} \mathrm{X}\right)
$$

where $\mathrm{BDE}\left(\mathrm{CH}_{3} \mathrm{X}\right)$ is the energy change in the reaction

$$
\mathrm{CH}_{3} \mathrm{X} \rightarrow{ }^{\bullet} \mathrm{CH}_{2} \mathrm{X}+{ }^{\bullet} \mathrm{H}
$$

The effect of remote substituents on bond dissociation energies (BDEs) has also been a topic of interest in the chemical literature. We note, for example, the experimental ${ }^{10}$ and theoretical $^{11,12}$ studies of the effect of meta or para substituents (X) on benzylic $\left(\mathrm{XC}_{6} \mathrm{H}_{4} \mathrm{CH}_{2}-\mathrm{Y}\right) \mathrm{C}-\mathrm{Y}$ BDEs. It was concluded that in the abstraction of $\mathrm{Y}$ from $p-\mathrm{XC}_{6} \mathrm{H}_{4} \mathrm{CH}_{2}-\mathrm{Y}$, the direction of the $\mathrm{C}-\mathrm{Y}$ dipole is the major rate-determining factor, and that when $\mathrm{Y}=\mathrm{H}$, an electron-withdrawing $\mathrm{X}$ increases the $\mathrm{C}-\mathrm{H}$ BDE whereas an electron-donating $\mathrm{X}$ decreases the $\mathrm{C}-\mathrm{H}$ BDE. Additionally, Zavitsas et al. ${ }^{11 a}$ investigated the effect of substituents $(\mathrm{X})$ on the allylic $\mathrm{C}-\mathrm{F}$ and $\mathrm{C}-\mathrm{H}$ BDEs in $\mathrm{XCH}=$ $\mathrm{CHCH}_{2}-\mathrm{F}$ and $\mathrm{XCH}=\mathrm{CHCH}_{2}-\mathrm{H}$. They found that similar types of electronic effects are present in allylic and benzylic systems, but that the effects transmitted through one double bond in allylic systems are greater than those transmitted through the aromatic ring in para-substituted benzylic systems.

In the present study, we systematically examine the effect of interposing various connector groups $(\mathrm{W})$ between the substituent $\mathrm{X}$ and the radical center, on $\mathrm{C}-\mathrm{H}$ bond dissociation energies and on the stabilities of the resultant carbon-centered radicals. For this purpose, we examine the $\mathrm{C}-\mathrm{H}$ BDEs for molecules $\mathrm{CH}_{3} \mathrm{WX}$ :

$$
\mathrm{CH}_{3} \mathrm{WX} \rightarrow{ }^{\bullet} \mathrm{CH}_{2} \mathrm{WX}+{ }^{\bullet} \mathrm{H}
$$

and the RSEs for the associated radicals ${ }^{\bullet} \mathrm{CH}_{2} \mathrm{WX}$ :

$$
{ }^{\circ} \mathrm{CH}_{2} \mathrm{WX}+\mathrm{CH}_{4} \rightarrow \mathrm{CH}_{3} \mathrm{WX}+{ }^{\bullet} \mathrm{CH}_{3}
$$

To assist in our analysis, it is convenient to define some additional quantities. First, we define the radical stabilization energy of ${ }^{\bullet} \mathrm{CH}_{2} \mathrm{WX}$ relative to that of ${ }^{\bullet} \mathrm{CH}_{2} \mathrm{WH}$ (designated $\mathrm{RSE}_{\mathrm{W}}$ ) as the energy change for the hydrogen-transfer reaction:

$$
{ }^{\bullet} \mathrm{CH}_{2} \mathrm{WX}+\mathrm{CH}_{3} \mathrm{WH} \rightarrow \mathrm{CH}_{3} \mathrm{WX}+{ }^{\bullet} \mathrm{CH}_{2} \mathrm{WH}
$$


This can be formulated alternatively in terms of $\mathrm{C}-\mathrm{H}$ bond dissociation energies as

$$
\mathrm{RSE}_{\mathrm{W}}\left({ }^{\circ} \mathrm{CH}_{2} \mathrm{WX}\right)=\mathrm{BDE}\left(\mathrm{CH}_{3} \mathrm{WH}\right)-\mathrm{BDE}\left(\mathrm{CH}_{3} \mathrm{WX}\right)
$$

or, equivalently

$$
\mathrm{RSE}_{\mathrm{W}}\left({ }^{\bullet} \mathrm{CH}_{2} \mathrm{WX}\right)=\operatorname{RSE}\left({ }^{\circ} \mathrm{CH}_{2} \mathrm{WX}\right)-\operatorname{RSE}\left({ }^{\bullet} \mathrm{CH}_{2} \mathrm{WH}\right)
$$

If there is no connector group (referred to subsequently as $\mathrm{W}=\mathrm{NIL}$ ), the RSE (in this case termed $\mathrm{RSE}_{0}$ ) is given by

$$
\mathrm{RSE}_{0}\left({ }^{\bullet} \mathrm{CH}_{2} \mathrm{X}\right)=\operatorname{BDE}\left(\mathrm{CH}_{4}\right)-\operatorname{BDE}\left(\mathrm{CH}_{3} \mathrm{X}\right)
$$

and is equal to the energy change for the reaction

$$
{ }^{\circ} \mathrm{CH}_{2} \mathrm{X}+\mathrm{CH}_{4} \rightarrow \mathrm{CH}_{3} \mathrm{X}+{ }^{\circ} \mathrm{CH}_{3}
$$

Thus, $\mathrm{RSE}_{\mathrm{W}}$ carries over, in the limit of no connector group, to the conventional definitions of eqs 2 and 1, respectively.

It is convenient to define also the radical connector energy (RCE) of $\left({ }^{\bullet} \mathrm{CH}_{2} \mathrm{WX}\right)$ as the energy change for the formal reaction:

$$
{ }^{\circ} \mathrm{CH}_{2} \mathrm{WX}+{ }^{\circ} \mathrm{CH}_{3} \rightarrow{ }^{\circ} \mathrm{CH}_{2} \mathrm{WH}+{ }^{\circ} \mathrm{CH}_{2} \mathrm{X}
$$

This measures how the connector group $\mathrm{W}$ affects the interaction between $\mathrm{X}$ and ${ }^{\bullet} \mathrm{CH}_{2}$, relative to that between $\mathrm{H}$ and ${ }^{\bullet} \mathrm{CH}_{2}$. A positive value of the RCE indicates that $\mathrm{W}$ enhances the interaction between $\mathrm{X}$ and ${ }^{\bullet} \mathrm{CH}_{2}$ relative to that between $\mathrm{H}$ and ${ }^{\bullet} \mathrm{CH}_{2}$.

In a similar manner, the molecule connector energy (MCE) is given by the energy change for the formal reaction:

$$
\mathrm{CH}_{3} \mathrm{WX}+\mathrm{CH}_{4} \rightarrow \mathrm{CH}_{3} \mathrm{WH}+\mathrm{CH}_{3} \mathrm{X}
$$

This measures how the connector group $\mathrm{W}$ affects the interaction between $\mathrm{X}$ and $\mathrm{CH}_{3}$ compared with that between $\mathrm{H}$ and $\mathrm{CH}_{3}$.

Finally, the effect of the connector group $\mathrm{W}$ on the RSE is given by the difference between $\mathrm{RSE}_{\mathrm{W}}$ and $\mathrm{RSE}_{0}$. It is easy to show that this is equal to the difference between the RCE and the MCE:

$$
\mathrm{RSE}_{\mathrm{W}}-\mathrm{RSE}_{0}=\mathrm{RCE}-\mathrm{MCE}
$$

The connector groups $(\mathrm{W})$ that we have examined in the present study include $-\mathrm{CH}_{2}-,-\mathrm{CH}=\mathrm{CH}-,-\mathrm{C} \equiv \mathrm{C}-,-p-\mathrm{C}_{6} \mathrm{H}_{4}-$, $-m-\mathrm{C}_{6} \mathrm{H}_{4}-$, and $-o-\mathrm{C}_{6} \mathrm{H}_{4}-$. The substituents (X) that we examine include $\mathrm{H}, \mathrm{CF}_{3}, \mathrm{CH}_{3}, \mathrm{CH}=\mathrm{O}, \mathrm{NH}_{2}$, and $\mathrm{CH}=\mathrm{CH}_{2}$.

\section{THEORETICAL PROCEDURES}

Standard ab initio molecular orbital theory ${ }^{13}$ and density functional theory ${ }^{14}$ (DFT) calculations were carried out with the Gaussian 03, ${ }^{15}$ Gaussian 09, ${ }^{16}$ and Molpro 2009.1 ${ }^{17}$ computer programs.

BDEs and RSEs were calculated with the high-level composite procedure G3X(MP2)-RAD, ${ }^{18}$ which approximates URCCSD $(\mathrm{T}) /$ G3XLarge energies computed at geometries optimized by the (U)B3-LYP/6-31G(2df,p) method (unrestricted version for openshell species). This procedure has previously been found to represent a good compromise between accuracy and affordability for predicting the thermochemistry of monosubstituted ${ }^{8 \mathrm{a}-\mathrm{c}}$ and multiply substituted ${ }^{9}$ radicals.

Single-point energy calculations were also carried out with the restricted-open-shell (RO) version ${ }^{19}$ of Grimme's B2-PLYP double-hybrid density functional theory procedure, ${ }^{20}$ in conjunction with the $6-311+\mathrm{G}(3 \mathrm{df}, 2 \mathrm{p})$ basis set at (U)B3-LYP/ $6-31 G(\mathrm{~d})$ geometries. The ROB2-PLYP method has 59\% HF exchange and $28 \% \mathrm{MP} 2$ correlation. It has been found to slightly (but consistently) underestimate the BDEs, giving a mean deviation (MD) of $-6.4 \mathrm{~kJ} \mathrm{~mol}^{-1}$ and a mean absolute deviation (MAD) of $6.4 \mathrm{~kJ} \mathrm{~mol}^{-1}$ from values calculated with the high-level W1 method, ${ }^{21}$ and -4.7 and $4.9 \mathrm{~kJ} \mathrm{~mol}^{-1}$, respectively, from available experimental BDEs. ${ }^{22}$ For RSEs, ROB2-PLYP yielded an MAD of $1.5 \mathrm{~kJ} \mathrm{~mol}^{-1}$ from $\mathrm{W} 1$ values and $2.7 \mathrm{~kJ} \mathrm{~mol}^{-1}$ from experimentally based RSEs. ${ }^{22}$ To obtain zero-point vibrational energies, the B3-LYP/6-31G(d) and B3-LYP/6-31G(2df,p) vibrational frequencies were scaled ${ }^{23}$ by 0.9806 and 0.9854 , respectively. The calculated energies in the text correspond to $\mathrm{G} 3 \mathrm{X}(\mathrm{MP} 2)-\mathrm{RAD}$ values at $0 \mathrm{~K}$, whereas corresponding ROB2$\mathrm{PLYP} / 6-311+\mathrm{G}(3 \mathrm{df}, 2 \mathrm{p})$ values at $0 \mathrm{~K}$ are given in the Supporting Information (Table S1).

Potential energy scans or conformational searches were carried out for the molecules and radicals, wherever necessary, to try to ensure that all conformations correspond to global rather than merely local minimum energy structures. The B3-LYP/6-31G(d) and B3-LYP/6-31G(2df,p) optimized geometries are given in Tables S3 and S4 (Supporting Information), respectively.

\section{RESULTS AND DISCUSSION}

Bond dissociation energies (BDEs), radical stabilization energies (RSEs and $\mathrm{RSE}_{\mathrm{w}} \mathrm{s}$ ), radical connector energies (RCEs), and molecule connector energies (MCEs) were calculated for $42 \mathrm{CH}_{3} \mathrm{WX}$ molecules and the related ${ }^{\bullet} \mathrm{CH}_{2} \mathrm{WX}$ radicals, for all combinations of the connector groups $\mathrm{W}$ shown in red in Figure 1 and the substituents $\mathrm{X}$ listed in the caption to this figure.

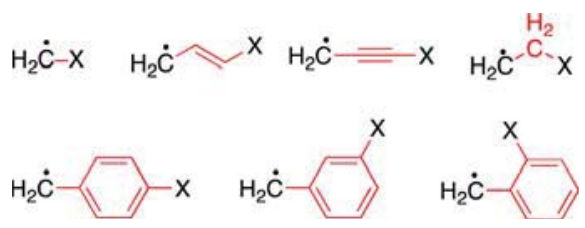

Figure $1 .{ }^{\circ} \mathrm{CH}_{2}-\mathrm{W}-\mathrm{X}$ systems examined in the present study, highlighting the various connector groups $\mathrm{W}$ in red $\left(\mathrm{X}=\mathrm{H}, \mathrm{CF}_{3}, \mathrm{CH}_{3}, \mathrm{CH}=\mathrm{O}\right.$, $\mathrm{NH}_{2}$, and $\mathrm{CH}=\mathrm{CH}_{2}$ ).

Table 1 presents the BDEs, RSEs, $\mathrm{RSE}_{\mathrm{w}} \mathrm{s}$, RCEs and MCEs calculated at the G3X(MP2)-RAD level. Corresponding values obtained at the ROB2-PLYP/6-311+G(3df,2p) level show very similar qualitative trends, with a mean absolute deviation from the G3X(MP2)-RAD values of $2.6 \mathrm{~kJ} \mathrm{~mol}^{-1}$ for the current set of radicals (see Table $\mathrm{S} 1$, Supporting Information).

3.1. Radical Stabilization Energies for ${ }^{\circ} \mathrm{CH}_{2} \mathrm{WX}$ Radicals $\left[\mathrm{RSE}\left({ }^{\circ} \mathrm{CH}_{2} \mathrm{WX}\right)\right]$. The effect of substituents $\mathrm{X}$ on the stability of carbon-centered radicals $\left({ }^{\bullet} \mathrm{CH}_{2} \mathrm{X}\right)$, in the absence of a connector group (designated $\mathrm{W}=\mathrm{NIL}$ ), has been extensively studied. ${ }^{3,8,9}$ The RSE values for W $=$ NIL in Table 1 confirm that carbon-centered radicals can be stabilized by $\pi$-electron donors (e.g., $\mathrm{X}=\mathrm{NH}_{2}, \mathrm{RSE}=45.2 \mathrm{~kJ} \mathrm{~mol}^{-1}$ ), $\pi$-electron acceptors (e.g., $\mathrm{X}=\mathrm{CHO}, \mathrm{RSE}=36.0 \mathrm{~kJ} \mathrm{~mol}^{-1}$ ) and, more weakly, by hyperconjugative donors (e.g., $\mathrm{X}=\mathrm{CH}_{3}, \mathrm{RSE}=14.5 \mathrm{~kJ} \mathrm{~mol}^{-1}$ ), whereas they are destabilized by strongly $\sigma$-electron-withdrawing groups $\left(\mathrm{X}=\mathrm{CF}_{3}, \mathrm{RSE}=-7.2 \mathrm{~kJ} \mathrm{~mol}^{-1}\right)$. A large positive RSE occurs when $\mathrm{X}$ is $\mathrm{CH}=\mathrm{CH}_{2}\left(\mathrm{RSE}=71.1 \mathrm{~kJ} \mathrm{~mol}^{-1}\right)$, which reflects the substantial resonance stabilization that the resultant allyl radical enjoys.

Substituents $(\mathrm{WH})$ that are related to the connector groups themselves $(\mathrm{W})$ play their own role in stabilizing or destabilizing the radical. For example, in ${ }^{\circ} \mathrm{CH}_{2} \mathrm{WH}$ radicals (i.e., ${ }^{\bullet} \mathrm{CH}_{2} \mathrm{WX}$ with $\mathrm{X}=\mathrm{H}$, entries $8-14$ in Table 1$)$, a vinyl group $(\mathrm{W}=-\mathrm{CH}=\mathrm{CH}-$, $\mathrm{RSE}$ of allyl radical is $\left.71.1 \mathrm{~kJ} \mathrm{~mol}^{-1}\right)$, a phenyl group $\left(\mathrm{W}=-\mathrm{C}_{6} \mathrm{H}_{4}-\right.$, 
Table 1. G3X(MP2)-RAD Bond Dissociation Energies (BDEs), Radical Stabilization Energies (RSEs and RSE $\mathbf{w}_{\mathrm{w}}$ ), Radical Connector Energies (RCEs), and Molecule Connector Energies (MCEs) in kJ mol ${ }^{-1}$ at $0 \mathrm{~K}$ for Species Related to $\mathrm{CH}_{3} \mathrm{WX}$ and ${ }^{\bullet} \mathrm{CH}_{2} \mathrm{WX}$

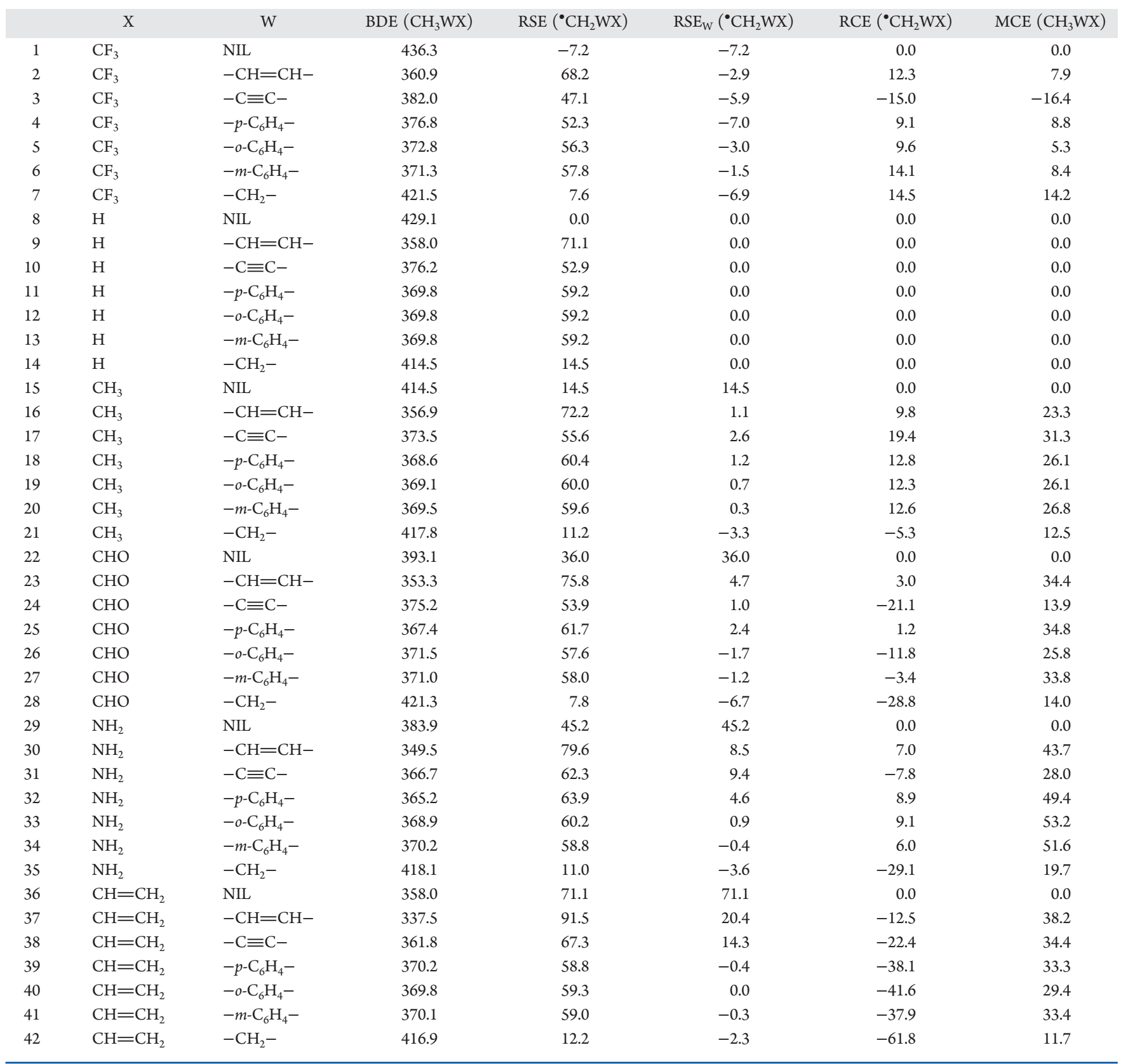

RSE of benzyl radical is $59.2 \mathrm{~kJ} \mathrm{~mol}^{-1}$ ) or an ethynyl group ( $\mathrm{W}=-\mathrm{C} \equiv \mathrm{C}-$, RSE of propargyl radical is $52.9 \mathrm{~kJ} \mathrm{~mol}^{-1}$ ) stabilize the radical center by conjugation, whereas the methyl group stabilizes the radical via hyperconjugation $\left(\mathrm{W}=-\mathrm{CH}_{2}-\mathrm{RSE}\right.$ of ethyl radical is $\left.14.5 \mathrm{~kJ} \mathrm{~mol}^{-1}\right)$.

If we examine the $\mathrm{RSE}\left({ }^{\bullet} \mathrm{CH}_{2} \mathrm{WX}\right)$ values listed in Table 1 more closely (Figure 2), we can see that they represent perturbations by $\mathrm{X}$ on the $\mathrm{RSE}\left({ }^{\bullet} \mathrm{CH}_{2} \mathrm{WH}\right)$ values noted above. For example, the RSEs when $\mathrm{W}$ is $-\mathrm{CH}=\mathrm{CH}-$ fall in the range $68.2-91.5 \mathrm{~kJ} \mathrm{~mol}^{-1}$, with values of $68.2\left(\mathrm{X}=\mathrm{CF}_{3}\right), 71.1(\mathrm{X}=\mathrm{H})$, $72.2\left(\mathrm{X}=\mathrm{CH}_{3}\right), 75.8(\mathrm{X}=\mathrm{CH}=\mathrm{O}), 79.6\left(\mathrm{X}=\mathrm{NH}_{2}\right)$, and 91.5 $\left(\mathrm{X}=\mathrm{CH}=\mathrm{CH}_{2}\right) \mathrm{kJ} \mathrm{mol}^{-1}$. Likewise, when $\mathrm{W}$ is $-\mathrm{C} \equiv \mathrm{C}-$, the RSEs fall in the range $47.1-67.3 \mathrm{~kJ} \mathrm{~mol}^{-1}$ (including $52.9 \mathrm{~kJ}$ $\mathrm{mol}^{-1}$ when $\mathrm{X}=\mathrm{H}$ ), whereas when $\mathrm{W}$ is $-p-\mathrm{C}_{6} \mathrm{H}_{4}-$, the RSEs are in the range $52.3-63.9 \mathrm{~kJ} \mathrm{~mol}^{-1}$ (including $59.2 \mathrm{~kJ} \mathrm{~mol}^{-1}$ when
$\mathrm{X}=\mathrm{H}$ ). For $\mathrm{W}=-\mathrm{CH}_{2}-$, the $\mathrm{RSE}$ for $\mathrm{X}=\mathrm{H}$ is $14.5 \mathrm{~kJ} \mathrm{~mol}^{-1}$, whereas it is in the range $7.6-12.2 \mathrm{~kJ} \mathrm{~mol}^{-1}$ for the other substituents.

Figure 2 also indicates that the transmission of electronic effects by the $-\mathrm{CH}=\mathrm{CH}-$ and $-\mathrm{C} \equiv \mathrm{C}-$ groups is such that the RSEs of ${ }^{\bullet} \mathrm{CH}_{2} \mathrm{WX}$ follow the same trends as those for ${ }^{\bullet} \mathrm{CH}_{2} \mathrm{X}$; e.g., the RSEs are generally the highest when $\mathrm{X}$ is $-\mathrm{CH}=\mathrm{CH}_{2}$ and the lowest when $\mathrm{X}$ is $\mathrm{CF}_{3}$, consistent with the trend seen in the absence of any connector groups (i.e., $\mathrm{W}=\mathrm{NIL}$ ). On the other hand, the $-p-\mathrm{C}_{6} \mathrm{H}_{4}-$ connector is inferior to $-\mathrm{CH}=\mathrm{CH}-$ at transmitting the effect of $\mathrm{X}$, whereas the $-o-\mathrm{C}_{6} \mathrm{H}_{4}-$ and $-m-\mathrm{C}_{6} \mathrm{H}_{4}-$ groups are relatively poor transmitters, in that the RSEs of ${ }^{\circ} \mathrm{CH}_{2} \mathrm{WX}$ in these cases are almost independent of the nature of X. Likewise, $-\mathrm{CH}_{2}-$ is a poor $\pi$-electron-transmitting group, and the RSEs here largely reflect the $\sigma$-electron effect of X. 


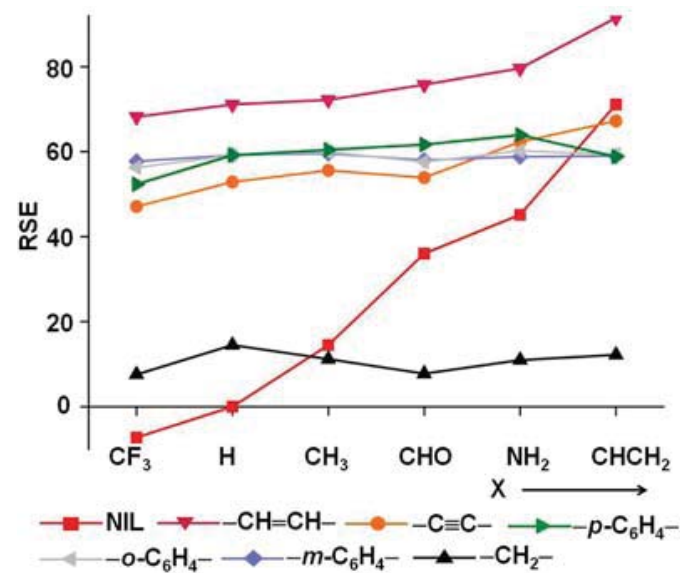

Figure 2. Variations with $\mathrm{X}$ of $\mathrm{RSE}\left({ }^{\bullet} \mathrm{CH}_{2} \mathrm{WX}\right)$ values for various connector groups $\mathrm{W}$ ( $\left.\mathrm{G} 3 \mathrm{X}(\mathrm{MP} 2)-\mathrm{RAD}, \mathrm{kJ} \mathrm{mol}^{-1}\right)$.

For example, there is a lowering of the RSE for the $\mathrm{CF}_{3}$ and other electron-withdrawing substituents $\left(\mathrm{CH}=\mathrm{O}\right.$ and $\left.\mathrm{NH}_{2}\right)$ when $\mathrm{W}=-\mathrm{CH}_{2}-$.

The similar qualitative trends in the transmission of electronic effects when $\mathrm{W}=-\mathrm{CH}=\mathrm{CH}-,-\mathrm{C} \equiv \mathrm{C}-$, and $-p-\mathrm{C}_{6} \mathrm{H}_{4}-$ compared with ${ }^{\circ} \mathrm{CH}_{2} \mathrm{X}$, may be rationalized in terms of the resonance structures in Figure 3. Specifically, we can see that, in each case, there is a contributing resonance structure in which $\mathrm{X}$ is directly attached to the radical center. Thus the radical center enjoys the superimposed stabilizing effects of the group related to the connector (WX), as well as that of the substituent $\mathrm{X}$. In the case of the $-m-\mathrm{C}_{6} \mathrm{H}_{4}-$ and $-\mathrm{CH}_{2}-$ connector groups, this is not possible. An unexpected result is that the effect of interposing an $-o-\mathrm{C}_{6} \mathrm{H}_{4}-$ group is not comparable to that of an interposed $-p-\mathrm{C}_{6} \mathrm{H}_{4}-$, despite the fact that appropriate resonance structures can still be drawn in this case. This may be associated with unfavorable steric interactions.

3.2. Radical Stabilization Energies for ${ }^{\bullet} \mathrm{CH}_{2} \mathrm{WX}$ Radicals Relative to ${ }^{\circ} \mathrm{CH}_{2} \mathrm{WH}$. The effects shown in Figure 2 are perhaps more clearly indicated by the $\mathrm{RSE}_{\mathrm{W}}$ values, included in Table 1 and displayed in Figure 4. The RSE $\mathrm{W}_{\mathrm{W}} \mathrm{s}$ are the energy changes for reaction 6 and correspond to the values of $\mathrm{RSE}\left({ }^{\circ} \mathrm{CH}_{2} \mathrm{WX}\right)$ relative to $\mathrm{RSE}\left({ }^{\bullet} \mathrm{CH}_{2} \mathrm{WH}\right)$. The $\mathrm{RSE}_{\mathrm{W}} \mathrm{s}$ also indicate the extent to which the influence of $\mathrm{X}$ is attenuated by the interposition of various connector groups. Figure 4 shows that the transmission of interactions is largest when $\mathrm{W}=-\mathrm{CH}=\mathrm{CH}-$ and smallest when $\mathrm{W}=-\mathrm{CH}_{2}-$. It also shows that a triple bond $(-\mathrm{C} \equiv \mathrm{C}-)$ is not always as effective in this respect as a double bond $(-\mathrm{CH}=$ $\mathrm{CH}-)$, but usually better than $p$-phenylene $\left(-p-\mathrm{C}_{6} \mathrm{H}_{4}-\right)$. The very small $\mathrm{RSE}_{\mathrm{W}}$ values for the $o$ - and $m$-phenylene groups indicate that these groups hardly transmit the effect of $\mathrm{X}$. The

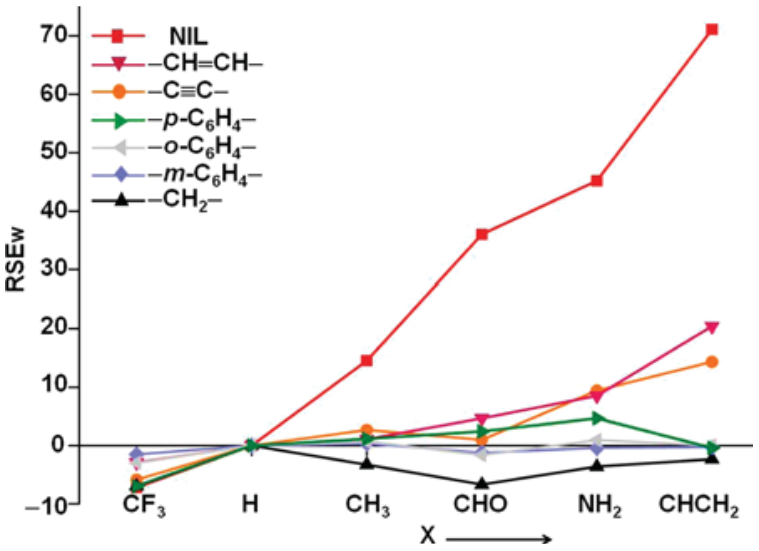

Figure 4. Variations with $\mathrm{X}$ of $\mathrm{RSE}_{\mathrm{W}}$ values for ${ }^{\bullet} \mathrm{CH}_{2} \mathrm{WX}$ for various connector groups $\mathrm{W}$ ( $\left.\mathrm{G} 3 \mathrm{X}(\mathrm{MP2})-\mathrm{RAD}, \mathrm{kJ} \mathrm{mol}^{-1}\right)$.

methylene $\left(-\mathrm{CH}_{2}-\right)$ group not only acts largely as an insulating group between the radical center and the substituent $\mathrm{X}$ but also leads even to negative $\mathrm{RSE}_{\mathrm{W}}$ values $\left(-2.3\right.$ to $\left.-6.9 \mathrm{~kJ} \mathrm{~mol}^{-1}\right)$. In several cases (e.g., $\mathrm{CF}_{3}, \mathrm{CH}=\mathrm{O}$, and $\mathrm{NH}_{2}$ ), this reflects a $\sigma$-withdrawing and thus radical destabilizing effect. In addition, recognizing that $\mathrm{RSE}_{\mathrm{w}}-\mathrm{RSE}_{0}=\mathrm{RCE}-\mathrm{MCE}$ (eq 13), we note also that there are contributions to the negative $\mathrm{RSE}_{\mathrm{W}}$ values that arise in several cases from the positive MCE values (see section 3.3 below). Our results are consistent with the earlier finding of Zavitsas et al. ${ }^{11 a}$ that the double bond of allyl is a better transmitter of electronic effects than the aromatic system of $p$-phenylene.

3.3. Decomposition into Radical Connector Energies (RCEs) and Molecule Connector Energies (MCEs). The $\mathrm{RSE}_{\mathrm{W}}$ values indicate the extent to which the influence of $\mathrm{X}$ is attenuated by the interposition of various connector groups $\mathrm{W}$. If $\mathrm{X}$ is directly connected to the radical center (i.e., $\mathrm{W}=\mathrm{NIL}$ ), then the resultant RSE (i.e., $\mathrm{RSE}_{0}$ ) is the standard radical stabilization energy as defined by reaction 10 . The differences between $\mathrm{RSE}_{\mathrm{W}}$ and $\mathrm{RSE}_{0}$ can be quite substantial and it is of interest to try to understand their origin. This is best illustrated through a few examples.

If $\mathrm{X}=\mathrm{NH}_{2}$ and $\mathrm{W}=-\mathrm{C} \equiv \mathrm{C}-($ entry 31 in Table 1$)$, then $\mathrm{RSE}_{\mathrm{W}}$ is the energy change for the reaction

$$
\begin{aligned}
& { }^{\bullet} \mathrm{CH}_{2}-\mathrm{C} \equiv \mathrm{C}-\mathrm{NH}_{2}+\mathrm{CH}_{3}-\mathrm{C} \equiv \mathrm{C}-\mathrm{H} \\
& \rightarrow \mathrm{CH}_{3}-\mathrm{C} \equiv \mathrm{C}-\mathrm{NH}_{2}+{ }^{\circ} \mathrm{CH}_{2}-\mathrm{C} \equiv \mathrm{C}-\mathrm{H}
\end{aligned}
$$

which is $9.4 \mathrm{~kJ} \mathrm{~mol}^{-1}$. This is substantially less than $\mathrm{RSE}_{0}$, the energy of the reaction in the absence of the ethynyl connector group $\left(\mathrm{RSE}_{\mathrm{W}}\right.$ for entry 29 in Table 1$)$ :

$$
{ }^{\circ} \mathrm{CH}_{2}-\mathrm{NH}_{2}+\mathrm{CH}_{4} \rightarrow \mathrm{CH}_{3}-\mathrm{NH}_{2}+{ }^{\circ} \mathrm{CH}_{3}
$$

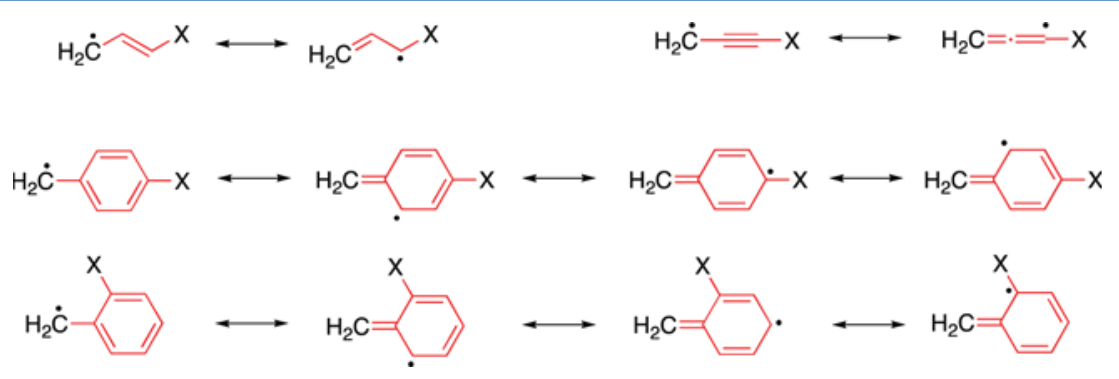

Figure 3. Resonance structures showing direct interaction of $\mathrm{X}$ with the radical center. 
whose large magnitude $\left(45.2 \mathrm{~kJ} \mathrm{~mol}^{-1}\right)$ reflects the large stabilizing effect of the amino group at a carbon radical center.

As noted earlier (eq 13), the difference between $\mathrm{RSE}_{\mathrm{W}}$ and $\operatorname{RSE}_{0}\left(-35.8 \mathrm{~kJ} \mathrm{~mol}^{-1}\right)$ is also given by the difference between the radical connector energy $\left(\mathrm{RCE}=-7.8 \mathrm{~kJ} \mathrm{~mol}^{-1}\right)$, in this case the energy of the reaction

$$
\begin{aligned}
& { }^{\circ} \mathrm{CH}_{2}-\mathrm{C} \equiv \mathrm{C}-\mathrm{NH}_{2}+{ }^{\circ} \mathrm{CH}_{3} \\
& \rightarrow{ }^{\circ} \mathrm{CH}_{2}-\mathrm{C} \equiv \mathrm{C}-\mathrm{H}+{ }^{\circ} \mathrm{CH}_{2}-\mathrm{NH}_{2}
\end{aligned}
$$

and the molecule connector energy $\left(\mathrm{MCE}=+28.0 \mathrm{~kJ} \mathrm{~mol}^{-1}\right)$, i.e., the energy of the reaction

$$
\begin{aligned}
& \mathrm{CH}_{3}-\mathrm{C} \equiv \mathrm{C}-\mathrm{NH}_{2}+\mathrm{CH}_{4} \\
& \rightarrow \mathrm{CH}_{3}-\mathrm{C} \equiv \mathrm{C}-\mathrm{H}+\mathrm{CH}_{3}-\mathrm{NH}_{2}
\end{aligned}
$$

Our results indicate that the reduction in RSE in going from $\mathrm{RSE}_{0}$ to $\mathrm{RSE}_{\mathrm{W}}$ is partly due to the unfavorable (negative) RCE but mainly to the favorable (positive) MCE. The negative RCE (eq 16) indicates that the sum of the stabilizing effects of individual ethynyl and amino groups at the radical center is greater than the effect of an aminoethynyl group, which seems reasonable. On the other hand, the strong positive MCE (eq 17) largely reflects the favorable donation of the lone pair of the amino group into the $\pi^{*}$ orbital of the triple bond in $\mathrm{CH}_{3} \mathrm{C} \equiv \mathrm{CNH}_{2}$.

As another example, if $\mathrm{X}$ is $\mathrm{CH}=\mathrm{CH}_{2}$ and $\mathrm{W}$ is $-\mathrm{CH}_{2}-$ (entry 42 in Table 1), then there is a very large reduction from $\mathrm{RSE}_{0}$ $\left(+71.1 \mathrm{~kJ} \mathrm{~mol}^{-1}\right.$, entry 36$)$ to $\mathrm{RSE}_{\mathrm{W}}\left(-2.3 \mathrm{~kJ} \mathrm{~mol}^{-1}\right)$ associated with the interposition of the $-\mathrm{CH}_{2}-$ connecting group in ${ }^{\bullet} \mathrm{CH}_{2} \mathrm{CH}_{2} \mathrm{CH}=\mathrm{CH}_{2}$. This reduction is largely attributable to the large negative $\mathrm{RCE}\left(-61.8 \mathrm{~kJ} \mathrm{~mol}^{-1}\right)$, i.e., the energy of the reaction

$$
\begin{aligned}
& { }^{\circ} \mathrm{CH}_{2}-\mathrm{CH}_{2}-\mathrm{CH}=\mathrm{CH}_{2}+{ }^{\circ} \mathrm{CH}_{3} \\
& \rightarrow{ }^{\circ} \mathrm{CH}_{2}-\mathrm{CH}_{3}+{ }^{\circ} \mathrm{CH}_{2}-\mathrm{CH}=\mathrm{CH}_{2}
\end{aligned}
$$

in addition to a small positive $\mathrm{MCE}\left(11.7 \mathrm{~kJ} \mathrm{~mol}^{-1}\right)$, i.e., the energy of the reaction

$$
\begin{aligned}
& \mathrm{CH}_{3}-\mathrm{CH}_{2}-\mathrm{CH}=\mathrm{CH}_{2}+\mathrm{CH}_{4} \\
& \rightarrow \mathrm{CH}_{3}-\mathrm{CH}_{3}+\mathrm{CH}_{3}-\mathrm{CH}=\mathrm{CH}_{2}
\end{aligned}
$$

It is of course not surprising that the $-\mathrm{CH}_{2}-$ connector disrupts the favorable interaction between the vinyl group and the radical center, leading to a large loss of stabilization in the radical (eq 18), and that the effect in the precursor molecule is much smaller (eq 19). Indeed, large negative RCEs are observed also for the $\mathrm{CH}=\mathrm{O}\left(-28.8 \mathrm{~kJ} \mathrm{~mol}^{-1}\right)$ and $\mathrm{NH}_{2}\left(-29.1 \mathrm{~kJ} \mathrm{~mol}^{-1}\right)$ substituents $(\mathrm{X})$ when the connecting group $(\mathrm{W})$ is $-\mathrm{CH}_{2}-$.

An overview of the trends in MCE and RCE values is displayed in Figure 5. We can see that, with only one exception (when the connector is $-\mathrm{C} \equiv \mathrm{C}-$ and $\mathrm{X}=\mathrm{CF}_{3}$ ), the $\mathrm{MCE}$ values are all positive. This indicates that the connector and $\mathrm{X}$ generally prefer to be in the same molecule $\left(\mathrm{CH}_{3} \mathrm{WX}\right)$ than in separate molecules $\left(\mathrm{CH}_{3} \mathrm{WH}\right.$ and $\left.\mathrm{CH}_{3} \mathrm{X}\right)$. On the other hand, the $\mathrm{RCE}$ values are sometimes positive and sometimes negative. Because the difference between $\mathrm{RSE}_{\mathrm{W}}$ and $\mathrm{RSE}_{0}$ is given by the difference between the RCE and MCE, the largest values of $\mathrm{RSE}_{\mathrm{w}}-\mathrm{RSE}_{0}$ appear when RCE and MCE have opposite signs. This is particularly the case when $\mathrm{X}=\mathrm{CH}=\mathrm{CH}_{2}$.

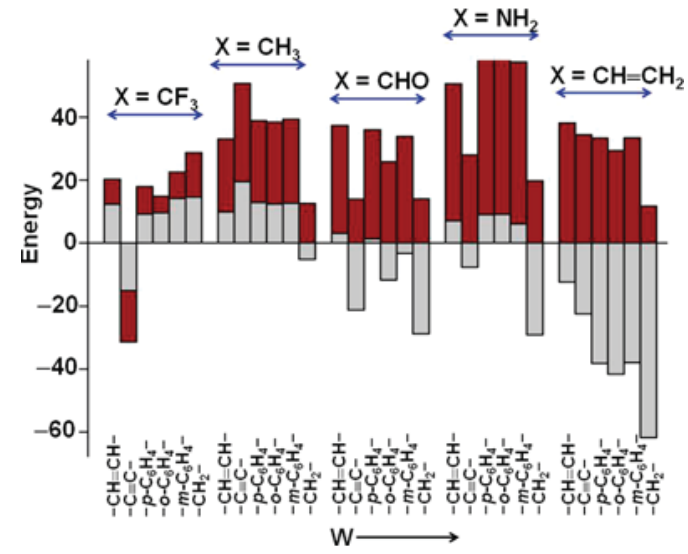

Figure 5. Calculated molecule connector energies (MCEs, red) and radical connector energies (RCEs, gray) (G3X(MP2)-RAD, $\mathrm{kJ} \mathrm{mol}^{-1}$ ).

\section{CONCLUSIONS}

(1) Among the connector groups (W) examined for radicals of the type ${ }^{\bullet} \mathrm{CH}_{2} \mathrm{WX}$, the effectiveness in transmission of the electronic effects of remote substituents $(\mathrm{X})$ to the radical center $\left({ }^{\bullet} \mathrm{CH}_{2}\right)$ decreases in the order $-\mathrm{CH}=\mathrm{CH}->$ $-\mathrm{C} \equiv \mathrm{C}->-p-\mathrm{C}_{6} \mathrm{H}_{4}->-o-\mathrm{C}_{6} \mathrm{H}_{4}-\sim-m-\mathrm{C}_{6} \mathrm{H}_{4}->$ $-\mathrm{CH}_{2}-$.

(2) In the case of the connector groups $-\mathrm{CH}=\mathrm{CH}-$ and $-\mathrm{C} \equiv \mathrm{C}-$, the effect of substituents is to represent a perturbation of the radical stabilization associated with the connector groups themselves (i.e., $\mathrm{CH}=\mathrm{CH}_{2}, \mathrm{C} \equiv \mathrm{CH}$ ). For example, when $\mathrm{X}=\mathrm{CF}_{3}$, there is a destabilizing perturbation, whereas when $\mathrm{X}=\mathrm{CH}=\mathrm{CH}_{2}$ there is a stabilizing perturbation. These may be measured using radical stabilization energies calculated relative to ${ }^{\circ} \mathrm{CH}_{2} \mathrm{WH}$, designated $\mathrm{RSE}_{\mathrm{W}}$.

(3) Analysis of the effect of interposing a connector group between the substituent and the radical center is facilitated by introducing additional quantities related to the effect in the radical [the radical connector energy (RCE)] and the effect in the precursor molecule [the molecule connector energy $(\mathrm{MCE})]$.

\section{- ASSOCIATED CONTENT}

\section{S Supporting Information}

Full citations are given for refs 15-17. Bond dissociation energies (BDEs), radical stabilization energies (RSEs and $\mathrm{RSE}_{\mathrm{W}} \mathrm{s}$ ), radical connector energies (RCEs), and molecule connector energies (MCEs) for species related to $\mathrm{CH}_{3} \mathrm{WX}$ and ${ }^{\bullet} \mathrm{CH}_{2} \mathrm{WX}$ and calculated at the ROB2-PLYP/6-311+G(3df,2p)/UB3-LYP/6$31 \mathrm{G}(\mathrm{d})$ level (Table $\mathrm{S} 1$ ). Total energies of substituted methanes $\mathrm{CH}_{3} \mathrm{WX}$ and substituted methyl radicals ${ }^{\circ} \mathrm{CH}_{2} \mathrm{WX}$, calculated at the G3X(MP2)-RAD and ROB2-PLYP/6-311+G(3df,2p) levels (Table S2). B3-LYP/6-31G(d) and B3-LYP/6-31G(2df,p) optimized geometries (Tables S3 and S4). This material is available free of charge via the Internet: http://pubs/acs.org.

\section{AUTHOR INFORMATION}

Notes

The authors declare no competing financial interest.

\section{ACKNOWLEDGMENTS}

We gratefully acknowledge the award of a Henry Bertie Florence Mabel Gritton Scholarship (to A.S.M.), an Australian Professorial Fellowship (to L.R.), funding from the ARC Centre of Excellence 
for Free Radical Chemistry and Biotechnology, and generous allocations of computer time (to L.R.) from the National Computational Infrastructure (NCI) National Facility and Intersect Australia Ltd. T.B. and A.S.M. thank the Swiss National Science Foundation for support under project No. 200020-121747.

\section{REFERENCES}

(1) See for example: (a) Viehe, H. G.; Merenyi, R.; Stella, L.; Janousek, Z. Angew. Chem., Int. Ed. Engl. 1979, 18, 917-932. (b) Viehe, H. G.; Merenyi, R.; Janousek, Z. Pure Appl. Chem. 1988, 60, 1635-1644. (c) Montevecchi, P. C.; Navacchia, M. L. J. Org. Chem. 1998, 63, 537542. (d) Viehe, H. G.; Janousek, Z.; Merenyi, R.; Stella, L. Acc. Chem. Res. 1985, 18, 148-154. (e) J. Hioe, J.; Zipse, H. Org. Biomol. Chem. 2010, 8 , 3609-3617. (f) Stella, L.; Janousek, Z.; Merenyi, R.; Viehe, H. G. Angew. Chem., Int. Ed. Engl. 1978, 17, 691-692.

(2) See for example: Coote, M. L.; Henry, D. J. Macromolecules 2005, $38,1415-1433$.

(3) See for example: (a) Block, D. A.; Yu, D.; Armstrong, D. A.; Rauk, A. Can. J. Chem. 1998, 76, 1042-1049. (b) Rauk, A.; Yu, D.; Taylor, J.; Shustov, G. V.; Block, D. A.; Armstrong, D. A. Biochemistry 1999, 38, 9089-9096. (c) Rauk, A.; Yu, D.; Armstrong, D. A. J. Am. Chem. Soc. 1997, 119, 208-217. (d) Yu, D.; Rauk, A.; Armstrong, D. A. J. Am. Chem. Soc. 1995, 117, 1789-1796. (e) Armstrong, D. A.; Yu, D.; Rauk, A. Can. J. Chem. 1996, 74, 1192-1199. (f) Meng, X. M.; Zou, L. F.; Xie, M.; Fu, Y. Chin. J. Chem. 2008, 26, 787-793. (g) Webster, N. R.; Nunn, J. F. Br. J. Anaesth. 1988, 60, 98-108. (h) Gaudiano, G.; Koch, T. H. Chem. Res. Toxicol. 1991, 4, 2-16. (i) Croft, A.; Easton, C. J.; Kociuba, K.; Radom, L. Tetrahedron Asymm. 2003, 14, 2919-2926. (j) Croft, A.; Easton, C. J.; Radom, L. J. Am. Chem. Soc. 2003, 125, 4119-4124. (k) Himo, F. Chem. Phys. Lett. 2000, 328, 270-276. (1) Li, M. J.; Liu, L.; Wei, K.; Fu, Y.; Guo, Q. X. J. Phys. Chem. B 2006, 110, 13582-13589. (m) Hioe, J.; Zipse, H. Faraday Discuss. 2010, 145, 301-313.

(4) See for example: Fukaya, H.; Ono, T.; Abe, T. J. Comput. Chem. 1998, 19, 277-289.

(5) For recent reviews, see: (a) Zipse, H. Top. Curr. Chem. 2006, 263, 163-189. (b) Coote, M. L.; Lin, C. Y.; Zipse, H. The Stability of Carbon-Centered Radicals. In Carbon-Centered Free Radicals and Radical Cations: Structure, Dynamics and Reactivity; Forbes, M. D. E., Ed.; Wiley: Hoboken, NJ, 2010; pp 83-104. (c) Hioe, J.; Zipse, H. Radical Stability - Thermochemical Aspects. In Encyclopedia of Radicals in Chemistry, Biology and Materials, Chatgilialoglu, C. Studer, A., Eds.; John Wiley \& Sons: Chichester, U.K., 2012; pp 449-476.

(6) Luo, Y.-R. Comprehensive Handbook of Chemical Bond Energies; Taylor \& Francis: Boca Raton, FL, 2007; see also references therein.

(7) See, for example: (a) Blanksby, S. J.; Ellison, G. B. Acc. Chem. Res. 2003, 36, 255-263. (b) Brocks, J. J.; Beckhaus, H. D.; Beckwith, A. L. J.; Ruchardt, C. J. Org. Chem. 1998, 63, 1935-1943.

(8) See for example: (a) Henry, D. J.; Parkinson, C. J.; Mayer, P. M.; Radom, L. J. Phys. Chem. A 2001, 105, 6750-6756 and references therein. (b) Menon, A. S.; Wood, G. P. F.; Moran, D.; Radom, L. J. Phys. Chem. A 2007, 111, 13638-13644 and references therein. (c) Menon, A. S.; Wood, G. P. F.; Moran, D.; Radom, L. J. Phys. Chem. A 2008, 112, 5554. (d) Henry, D. J.; Radom, L. In Quantum-Mechanical Prediction of Thermochemical Data; Cioslowski, J., Ed.; Kluwer Academic: Dordrecht, The Netherlands, 2001; pp 161-197. (e) Neese, F.; Schwabe, T.; Kossmann, S.; Schirmer, B.; Grimme, S. J. Chem. Theory Comput. 2009, 5, 3060-3073. (f) Coote, M. L.; Lin, C. Y.; Beckwith, A. L.; Zavitsas, A. A. Phys. Chem. Chem. Phys. 2010, 12, 9597-9610. (g) Chan, B; Radom, L. J. Phys. Chem. A 2012, 116, 4975-4986.

(9) Menon, A. S.; Henry, D. J.; Bally, T.; Radom, L. Org. Biomol. Chem. 2011, 9, 3636-3657 and references therein.

(10) (a) Jackson, R. A.; Sharifi, M. J. Chem. Soc. Perk. T. 2 1996, 775778. (b) Fisher, T. H.; Dershem, S. M.; Prewitt, M. L. J. Org. Chem. 1990, 55, 1040-1043.

(11) (a) Zavitsas, A. A.; Rogers, D. W.; Matsunaga, N. J. Org. Chem. 2007, 72, 7091-7101 and references therein. (b) Rogers, D. W.; Zavitsas, A. A.; Matsunaga, N. J. Phys. Chem. A 2009, 113, 12049-12055. (c) Zavitsas, A. A.; Pinto, J. A. J. Am. Chem. Soc. 1972, 94, 7390-7396. (d) Jonsson, M.; Lind, J.; Merenyi, G.; Eriksen, T. E. J. Chem. Soc., Perkin Trans. 2 1994, 2149-2154.

(12) (a) Fu, Y.; Liu, L.; Lin, B. L.; Mou, Y.; Cheng, Y. H.; Guo, Q. X. J. Org. Chem. 2003, 68, 4657-4662. (b) Wen, Z.; Li, Z.; Shang, Z.; Cheng, J. P. J. Org. Chem. 2001, 66, 1466-1472.

(13) (a) Hehre, W. J.; Radom, L.; Schleyer, P. v. R.; Pople, J. A. Ab Initio Molecular Orbital Theory; John Wiley \& Sons, Inc.: New York, 1986. (b) Jensen, F. Introduction to Computational Chemistry, 2nd ed.; John Wiley and Sons, Ltd: Chichester, U.K., 2007.

(14) Koch, W.; Holthausen, M. C. A Chemist's Guide to Density Functional Theory, 2nd ed.; Wiley: New York, 2001.

(15) Frisch, M. J.; Trucks, G. W.; Schlegel, H. B.; Scuseria, G. E.; Robb, M. A.; Cheeseman, J. R.; Montgomery, Jr., J. A.; Vreven, T.; Kudin, K. N.; Burant, J. C.; et al. Gaussian 03, Revision E.01; Gaussian, Inc.: Wallingford, CT, 2004 (full citation given in the Supporting Information)

(16) Frisch, M. J.; Trucks, G. W.; Schlegel, H. B.; Scuseria, G. E.; Robb, M. A.; Cheeseman, J. R.; Scalmani, G.; Barone, V.; Mennucci, B.; Petersson, G. A.; et al. Gaussian 09, Revision A.1; Gaussian, Inc., Wallingford, CT, 2009 (full citation given in the Supporting Information).

(17) Werner, H.-J.; Knowles, P. J.; Lindh, R.; Manby, F. R.; Schütz, M.; Celani, P.; Korona, T.; Mitrushenkov, A.; Rauhut, G.; B. Adler, T.; et al. MOLPRO 2009.1, see http:www.molpro.net (full citation given in the Supporting Information).

(18) Henry, D. J.; Sullivan, M. B.; Radom, L. J. Chem. Phys. 2003, 118, 4849-4860.

(19) Graham, D. C.; Menon, A. S.; Goerigk, L.; Grimme, S.; Radom, L. J. Phys. Chem. A 2009, 113, 9861-9873.

(20) Grimme, S. J. Chem. Phys. 2006, 124, 034108-1-034108-16.

(21) (a) Martin, J. M. L.; Oliveira, d. G. J. Chem. Phys. 1999, 111, 1843-1856. (b) Martin, J. M. L. Chem. Phys. Lett. 1999, 310, 271-276.

(22) Calculated from the Supporting Information of ref 9.

(23) Scott, A. P.; Radom, L. J. Phys. Chem. 1996, 100, 16502-16513. 